\title{
FENOTIPSKE PROMJENE PRI SORTNOJ REPRODUKCIJI PŠENICE
}

\author{
PHENOTYPIC CHANGES \\ IN VARIETAL REPRODUCTION OF WHEAT \\ N. Đurić, Gorica Cvijanović, Gordana Dozet, Gordana Branković, V. \\ Cvijanović, S. Abuatwarat
}

\section{SAŽETAK}

Razvijeno i dobro organizirano sjemenarstvo podrazumijeva stalnu proizvodnju sjemena svih kategorija i na taj način održavanja nivoa genetske čistoće sorti pšenice. Ispitivane su tri sorte ozime pšenice Instituta PKB Agroekonomik različitih vrijednosti morfoloških osobina biljaka, rodnosti i osobina kvalitete zrna: PKB Kristina, PKB Roksanda i PKB Rodika. Svaka sorta pšenice uzgajana je u tri različite varijante agrotehničkih uvjeta, prilagođenih dobivanju tri kategorije sjemenskih usjeva: predosnovno sjeme, osnovno sjeme i certificiranono sjeme I. generacije. Kategorija sjemena predosnovno sjeme imala je najveće prosječne vrijednosti za obje godine istraživanja za ispitivane osobine: broj sekundarnih izdanaka, broj klasića u klasu i broj zrna u klasu. Kategorija sjemena predosnovno sjeme ima najveći broj klasića u klasu, što pokazuje da se oni razvijaju na dužim klasovima nego ostale kategorije sjemena. Kategorija sjemena predosnovno sjeme na osnovi ove karakteristike ima potencijal za formiranje većeg broja zrna u klasu nego ostale ispitivane kategorije sjemena. Kategorija sjemena certificirano sjeme I. generacije ima najmanji broj i najsitnija zrna, jer se ova kategorija sjemena proizvodi u najvećoj gustoći.

Ključne riječi: pšenica, kategorije sjemena, fenotipske promjene.

\section{ABSTRACT}

Developed and well organized seed production implies constant production of seeds of all categories and thus maintaining the level of genetic purity of wheat varieties. Three varieties of the Institute PKB Agroekonomik winter wheat, PKB Kristina, PKB Roksanda and PKB Rodika, of different value 
morphological characteristics of plants, level of fertility and grain quality characteristics were investigated. Each wheat variety was grown in three different variants of agritehnical conditions, adapted for obtaining three categories of seed plants: prebasic seed, basic seed and $1^{\text {st }}$ generation certified seed. The prebasic seed category had the highest average values in both years of the experiment in the following examined traits: number of secondary shoots, number of spikelets in the spike and number of seeds per spike. The prebasic seed category had the highest number of spikelets in the spike which indicates that they develop on longer spikes than the other categories of seeds. Based on this characteristic, the prebasic seed category has the potential to form more seeds per spike than other investigated seed categories. The $1^{\text {st }}$ generation certified seed category had the lowest number of seeds and the smallest seeds, because this seed category is produced in the highest density.

Key words: wheat, seed category, phenotypic changes.

\section{UVOD}

Pšenica, predstavlja najznačajnije krušno žito, kojim se u današnje vrijeme hrani preko $70 \%$ stanovništva zemljine kugle (Glamočlija, 2012.). U posljednjih 20 godina površine pod pšenicom u svijetu variraju i kreću se od oko 212,0 milijuna hektara (2006.) do 223,5 milijuna hektara (2014.). Proizvodnja pšenice $\mathrm{u}$ svijetu je u stalnom porastu s prosječnim prinosom koji varira od 2,91 tha-1 koliko iznosi svjetski prosjek do 3,65 t ha-1 koliko iznosi evropski prosjek. Prosjek u Srbiji iznosi 3,8 tha-1. Godišnja potrošnja pšenice u svijetu iznosi oko 620 milijuna tona (Đurić i sur. 2015.).

Selekcija pšenice u vidu sistematskog oplemenjivanja na prostoru Balkana počela je u prvoj polovici XIX. stoljeća. Prve sorte pšenice stvorene metodom individualnog odabiranja (Pedigre metoda) pojavile su se u proizvodnji u drugoj polovini XIX. stoljeća. Od tada na važnosti dobiva i sortno sjemenarstvo pšenice zbog: održavanja proizvodnih osobina sorata, održavanja zdravstvenog stanja sorata, tehnoloških osobina sorata, zaštita prava autora sorata i proizvođača sjemena (Đurić, 2013.). Današnje sorte pšenice predstavljaju genetički visokoselekcionirane biotehničke materijale. U Srbiji danas su najviše u upotrebi sorte umnožene linije dobivene individualnim odabiranjem, ali su se zadnjih godina pojavile i hibridne pšenice.

Đurić i sur. (2008.) konstatirali su da je za postizanje stabilnih prinosa u prvom redu neophodno koristiti kvalitetno sjeme za sjetvu, što i jest primarni zadatak sjemenarstva. 
N. Đurić i sur.: Fenotipske promjene pri sortnoj reprodukciji pšenice

Prodanović i sur. (2009.) su istraživali i uspoređivali prosječne vrijednosti kvantitativnih osobina sorti pšenice kod individualnih biljaka i kod biljaka $u$ usjevu (550 biljaka $/ \mathrm{m}^{2}$ ). Iznenađujuće je da su najmanje vrijednosti za osobine masa zrna po klasu i broj zrna po klasu imale individualne biljke.

Anderson i Barclay (1991.) su ispitivali sorte pšenice i njihov fenotip $u$ zavisnosti od gustoće sjetve. Proučavali su veći broj osobina i njihovu međuzavisnost kod tri sorte. Utvrdili su da se obrazuju duži klasovi kada je gustoća populacije manja, ali se pri tome ne povećava broj zrna po kvadratnom metru.

Munkvold i sur. (2013.) konstatiraju da se kvantitativne fenotipske osobine razvijaju pod utijecajem fenotipa i promjenljivih faktora vanjske sredine, kao i interakcijom između njih. Posebno značajna je interakcija između genotipa i vanjske sredine (G x E) koja predstavlja utjecaj ekoloških faktora na ekspresiju gena.

Razvijeno i dobro organizirano sjemenarstvo podrazumijeva stalnu proizvodnju sjemena svih kategorija i na taj način održavanje nivoa genetske čistoće sorti pšenice.

Imperativi koji se postavljaju pred tehnologiju uzgajanja sjemenskih usjeva su: očuvanje sortne čistoće, što bolja sjemenska kvaliteta i što veći prinos (Prodanović, 2009.; Đurić , 2013.).

Prema shemi OECD (Organisation for Economic Cooperation and Development - Organizacije za ekonomsku suradnju i razvoj), koja se primjenjuje i u Srbiji kategorije sjemena pšenice su sljedeće: selekcionirano sjeme, predosnovno sjeme, osnovno sjeme, certificirano sjeme - I. generacije. Cilj ovog rada je da se sagledaju promjene fenotipa u sjemenarstvu pšenice, odnosno promjene fenotipa u različitim kategorijama pšenice.

\section{MATERIJAL I METODE RADA}

Poljski pokusi postavljeni su i izvedeni u Južnom Banatu na oglednim parcelama Instituta PKB Agroekonomik u Padinskoj Skeli. Tip zemljišta na kojemu su izvedeni mikropokusi je ritska crnica.

Ispitivana su po tri različita tretmana (varijante) za svaku od ovih sorti $u$ pogledu primjene selekcije i gustoće usjeva, koji odgovaraju zahtjevima za proizvodnju tri različite kategorije sjemena: predosnovno sjeme, osnovno sjeme i certificirano sjeme I. generacije. Biljke su u svakom od različitih proizvodnih uvjeta praćene uz mjerenje njihovih fenotipskih karakteristika. Iz svake je parcele uzimano po 40 biljaka za analizu po dijagonalama, odnosno 10 biljaka u četiri ponavljanja. 
N. Đurić i sur.: Fenotipske promjene pri sortnoj reprodukciji pšenice

Tri sorte ozime pšenice Instituta PKB Agroekonomik s različitim vrijednostima morfoloških osobina biljaka, rodnosti i osobina kvalitete zrna ispitivane u ovom radu su: PKB Kristina, PKB Roksanda i PKB Rodika. Ispitivane su sljedeće osobine: broj izdanaka, broj klasića u klasu, broj zrna u klasu, apsolutna masa zrna i masa zrna u klasu. Sve tri sorte ozime pšenice priznate su u zemljama Europske unije. Svaka sorta pšenice uzgajana je u tri različite varijante agrotehničkih uvjeta, prilagođenih dobivanju tri kategorije sjemenskih usjeva: predosnovno sjeme, osnovno sjeme i certificirano sjeme I. generacije.

Varijanta 1, „predosnovno sjeme“, realizirana je pod kontrolom i nadzorom selekcionara, odnosno uz primjenu metode negativnog odabiranja, tj. odbacivanja atipičnih redova $\mathrm{i}$ pozitivnog odabiranja tj. uzimanja najboljih klasova za proizvodnju selekcionarovog sjemena, pri čemu su ispitivane biljke i uzimano sjeme preostalih individua na polju. Sjetva predosnovnog sjemena obavljena je u parcelice od 6 redova, dužine $1 \mathrm{~m}$, s međurednim rastojanjem od $12 \mathrm{~cm}$.

Varijanta 2, „osnovno sjeme“, imala je veću gustoću usjeva, koja je dobivena sjetvom $120 \mathrm{~kg} \mathrm{ha}^{-1}$ predosnovnog sjemena u neprekidne redove na parceli. Nakon čišćenja od atipičnih biljaka ispitivane su osobine preostalih biljaka i uzimano je njihovo sjeme za analizu i dobivanje varijante 3.

Varijanta 3, „certificirano sjeme I. generacije“, imala je još veću gustoću dobivenu sjetvom $240 \mathrm{~kg} \mathrm{ha}^{-1}$ sjemena. Ispitivane su tipične biljke u ovoj varijanti i analizirana kvaliteta sjemena i karakteristike zrna. Sve tri varijante ispitivane su i analizirane $\mathrm{u}$ dvije istraživačke godine, tijekom vegetacijske 2013/2014 i 2014/2015. godine. Meteorološki uvjeti za vrijeme izvođenja pokusa predstavljeni su u tablici 1 .

Tablica 1. Pregled mjesečnih temperatura zraka i padavina za vegetacijski period pšenice tijekom izvođenja poljskog pokusa (2013/2014. i 2014/2015.g.).

Table 1 Review of monthly air temperatures and precipitation for the wheat vegetation period during the field experiment (2013/2014 and 2014/2015).

\begin{tabular}{|c|c|c|c|c|c|c|c|c|c|c|c|c|}
\hline \multirow{2}{*}{$\begin{array}{l}\text { Meteorološki } \\
\text { Faktor } \\
\text { Meteorological } \\
\text { factor }\end{array}$} & \multirow{2}{*}{$\begin{array}{l}\text { Godina } \\
\text { Year }\end{array}$} & \multicolumn{10}{|c|}{$\begin{array}{l}\text { Mjesec } \\
\text { Month }\end{array}$} & \multirow{2}{*}{$\begin{array}{l}\text { Prosjek } \\
\text { Average }\end{array}$} \\
\hline & & $\mathrm{X}$ & XI & XII & I & II & III & IV & V & VI & VII & \\
\hline \multirow{2}{*}{$\begin{array}{l}\text { Temperatura } \\
\text { Temperature }\end{array}$} & $2013 / 2014$ & 11.8 & 6.8 & 3.1 & -1.9 & 1.3 & 6.4 & 13.8 & 17.5 & 18.9 & 21.7 & \multirow{2}{*}{$\begin{array}{c}9.94 \\
9.6\end{array}$} \\
\hline & $2014 / 2015$ & 10.7 & 6.6 & 1.8 & -1.0 & 1.6 & 6.6 & 11.7 & 16.3 & 19.5 & 22.2 & \\
\hline \multirow{2}{*}{$\begin{array}{c}\text { Padavine } \\
\text { Precipitation }\end{array}$} & $2013 / 2014$ & 18.6 & 68 & 77 & 60.6 & 40.2 & 56.2 & 17 & 29.2 & 98.2 & 35.8 & \multirow{2}{*}{$\begin{array}{l}500.8 \\
750.8\end{array}$} \\
\hline & $2014 / 2015$ & 89.2 & 79.4 & 97 & 60.2 & 64.2 & 44.4 & 30.2 & 147.2 & 91 & 48 & \\
\hline
\end{tabular}


N. Đurić i sur.: Fenotipske promjene pri sortnoj reprodukciji pšenice

Trofaktorijalna analiza varijanse urađena je pomoću programa Statistica for Windows, 8.0.

\section{REZULTATI ISTRAŽIVANJA I DISKUSIJA}

Trofaktorijalna analiza varijance urađena je posebno za svaku ispitivanu osobinu (broj sekundarnih izdanaka, broj klasića u klasu, broj zrna u klasu, apsolutna masa 1000 zrna i za osobinu masa zrna u klasu). Rezultati su prikazani kao prosječan kvadrat i F-izračunato, a faktori su sorta pšenice (tri sorte), godina izvođenja poljskog pokusa (dvije godine), i kategorija sjemena (tri kategorije sjemena pšenice), u tablici 2.

\section{Tablica 2. Analiza varijance za ispitivane osobine}

Table 2 Analysis of variance for investigated characteristics

\begin{tabular}{|c|c|c|c|c|c|c|}
\hline \multirow[b]{2}{*}{$\begin{array}{c}\text { Izvor } \\
\text { varijacije } \\
\text { Source of } \\
\text { variation }\end{array}$} & \multirow[b]{2}{*}{ d.f. } & \multicolumn{5}{|c|}{$\begin{array}{c}\text { MS vrijednosti } \\
\text { MS values }\end{array}$} \\
\hline & & $\begin{array}{c}\text { Broj } \\
\text { izdanaka } \\
\text { No. of } \\
\text { shoots }\end{array}$ & $\begin{array}{l}\text { Broj klasića } \\
\text { u klasu } \\
\text { No. of } \\
\text { spikelets in } \\
\text { a spike }\end{array}$ & $\begin{array}{l}\text { Broj zrna } \\
\text { u klasu } \\
\text { No. of } \\
\text { grains in a } \\
\text { spike }\end{array}$ & $\begin{array}{c}\text { Apsolutna } \\
\text { masa zrna } \\
\text { Absolute } \\
\text { grain weight }\end{array}$ & $\begin{array}{c}\text { Masa zrna } \\
\text { u klasu } \\
\text { Grain } \\
\text { weight in } \\
\text { a spike }\end{array}$ \\
\hline $\begin{array}{c}\text { Tretmani } \\
\text { Treatments }\end{array}$ & 5 & $0,20 * *$ & $2,60 * *$ & $63,32 * *$ & $6,79 * *$ & $0,27^{* *}$ \\
\hline $\begin{array}{l}\text { Ponavljanja } \\
\text { Repetitions }\end{array}$ & 12 & 0,01 & 0,10 & 2,16 & 1,45 & 0,01 \\
\hline $\begin{array}{l}\text { Genotipovi } \\
\text { Genotypes }\end{array}$ & 2 & $0,13 * *$ & $0,76^{* *}$ & 6,21 & $212,60 * *$ & $1,27^{* *}$ \\
\hline $\begin{array}{c}\text { Genotip } \mathrm{x} \\
\text { tretman } \\
\text { Genotype } \mathrm{x} \\
\text { treatment }\end{array}$ & 10 & 0,01 & $0,72 * *$ & $21,57 * *$ & 1,55 & $0,06^{* *}$ \\
\hline $\begin{array}{l}\text { Greška } \\
\text { Error }\end{array}$ & 24 & 0,01 & 0,09 & 2,56 & 0,99 & 0,01 \\
\hline $\begin{array}{c}\text { Okruženje } \\
\text { Environment }\end{array}$ & 17 & 0,34 & 4,08 & 91,09 & 220,95 & 1,60 \\
\hline $\begin{array}{l}\text { Total } \\
\text { Total }\end{array}$ & 53 & 0,36 & 4,27 & 95,82 & 223,38 & 1,62 \\
\hline
\end{tabular}

Iz tablice trofaktorijalne analize varijance može se vidjeti da postoje vrlo visoke statistički značajne razlike između tretmana (varijanti) i genotipova za skoro svaku analiziranu osobinu, dok između ponavljanja nema razlika. Do sličnih rezultata došli su Akram i sur. (2008.), Petrović i sur. (2000.), Đurić i sur. (2010.) i Dimitrijević i sur. (2006.). 
N. Đurić i sur.: Fenotipske promjene pri sortnoj reprodukciji pšenice

Srednje vrijednosti ispitivanih osobina prikazane su u Tablicama 3, 4, 5 i 6, za eksperimentalno dobivene podatke, pri čemu su u svakoj datoj tablici prikazani rezultati ispitivanih osobina pšenice po određenim faktorima promatranja.

U tablici 3. prikazane su prosječne vrijednosti ispitivanih osobina: broj sekundarnih izdanaka, broj klasića u klasu, broj zrna u klasu, apsolutna masa 1000 zrna i masa zrna u klasu. Vrijednosti su prikazane za tri ispitivane sorte pšenice, po ispitivanim kategorijama sjemena i po ispitivanim godinama.

Tablica 3. Srednje vrijednosti ispitivanih osobina pšenice u odnosu na ispitivanu sortu, kategoriju sjemena i godinu ispitivanja

Table 3 Mean values for investigated characteristics of wheat by investigated variety, seed category and year of investigation

\begin{tabular}{|c|c|c|c|c|c|c|c|}
\hline $\begin{array}{l}\text { Sorta } \\
\text { Variety }\end{array}$ & $\begin{array}{l}\text { Kategorija } \\
\text { Category }\end{array}$ & $\begin{array}{l}\text { God. } \\
\text { Year }\end{array}$ & $\begin{array}{l}\text { Broj } \\
\text { sekun. } \\
\text { izdan. } \\
\text { No. of } \\
\text { second. } \\
\text { shoots } \\
\end{array}$ & $\begin{array}{c}\text { Broj } \\
\text { klasića u } \\
\text { klasu } \\
\text { No. of } \\
\text { spikelets } \\
\text { in a spike } \\
\end{array}$ & $\begin{array}{c}\text { Broj zrna } \\
\text { u klasu } \\
\text { No. of } \\
\text { grains in } \\
\text { a spike }\end{array}$ & $\begin{array}{c}\text { Apsol. } \\
\text { masa } 1000 \\
\text { zrna }(\mathrm{g}) \\
\text { Absolute } \\
1000 \text { grain } \\
\text { weight }(\mathrm{g})\end{array}$ & $\begin{array}{l}\text { Masa zrna } \\
\text { u klasu (g) } \\
\text { Grain } \\
\text { weight in } \\
\text { a spike (g) }\end{array}$ \\
\hline \multirow{6}{*}{ Kristina } & \multirow{2}{*}{$\begin{array}{l}\text { Predosnovno } \\
\text { sjeme } \\
\text { Prebasic seed }\end{array}$} & 2014 & 3,20 & 22,34 & 70,15 & 39,22 & 2,75 \\
\hline & & 2015 & 3,39 & 22,55 & 74,41 & 40,92 & 3,05 \\
\hline & \multirow{2}{*}{$\begin{array}{l}\text { Osnovno sjeme } \\
\text { Basic seed }\end{array}$} & 2014 & 3,14 & 20,82 & 65,64 & 40,21 & 2,64 \\
\hline & & 2015 & 3,41 & 21,63 & 68,60 & 41,14 & 2,82 \\
\hline & \multirow{2}{*}{$\begin{array}{l}\text { Certificirano } \\
\text { sjeme I gen. } \\
\text { Certified } 1^{\text {st }} \\
\text { generation seed }\end{array}$} & 2014 & 3,08 & 20,99 & 66,51 & 39,49 & 2,63 \\
\hline & & 2015 & 3,32 & 21,65 & 70,02 & 41,24 & 2,89 \\
\hline \multirow{6}{*}{ Roksanda } & \multirow{2}{*}{$\begin{array}{l}\text { Predosnovno } \\
\text { sjeme } \\
\text { Prebasic seed }\end{array}$} & 2014 & 3,05 & 21,11 & 67,05 & 38,36 & 2,57 \\
\hline & & 2015 & 3,14 & 21,25 & 67,69 & 39,03 & 2,64 \\
\hline & \multirow{2}{*}{$\begin{array}{l}\text { Osnovno sjeme } \\
\text { Basic seed }\end{array}$} & 2014 & 2,95 & 21,11 & 69,02 & 38,07 & 2,63 \\
\hline & & 2015 & 3,41 & 21,86 & 72,13 & 39,44 & 2,84 \\
\hline & \multirow{2}{*}{$\begin{array}{l}\text { Certificirano } \\
\text { sjeme I gen. } \\
\text { Certified } 1^{\text {st }} \\
\text { generation seed }\end{array}$} & 2014 & 2,98 & 20,95 & 67,68 & 38,03 & 2,57 \\
\hline & & 2015 & 3,14 & 21,24 & 69,45 & 38,86 & 2,70 \\
\hline \multirow{6}{*}{ Rodika } & \multirow{2}{*}{$\begin{array}{l}\text { Predosnovno } \\
\text { sjeme } \\
\text { Prebasic seed }\end{array}$} & 2014 & 3,04 & 21,25 & 68,58 & 45,69 & 3,13 \\
\hline & & 2015 & 3,34 & 23,05 & 76,92 & 46,70 & 3,59 \\
\hline & \multirow{2}{*}{$\begin{array}{l}\text { Osnovno sjeme } \\
\text { Basic seed }\end{array}$} & 2014 & 2,93 & 20,59 & 64,39 & 43,85 & 2,82 \\
\hline & & 2015 & 3,24 & 21,78 & 73,04 & 46,91 & 3,43 \\
\hline & \multirow{2}{*}{$\begin{array}{c}\text { Certificirano } \\
\text { sjeme I gen. } \\
\text { Certified } 1^{\text {st }} \\
\text { generation seed }\end{array}$} & 2014 & 2,95 & 20,83 & 65,84 & 43,14 & 2,84 \\
\hline & & 2015 & 3,19 & 21,37 & 71,10 & 45,03 & 3,20 \\
\hline
\end{tabular}


Ispitivana osobina broj sekundarnih izdanaka najveću zabilježenu vrijednost imala je u 2015. godini 3,41 kod dvije ispitivane sorte Kristina i Roksanda za kategoriju sjemena osnovno sjeme. Najmanju zabilježenu vrijednost ova osobina imala je u 2014. godini 2,93 kod sorte Rodika za kategoriju sjemena osnovno sjeme.

Osobina broj klasića u klasu najveću zabilježenu vrijednost imala je u 2015. godini 23,05 kod ispitivane sorte Rodika za kategoriju sjemena predosnovno sjeme. Najmanju zabilježenu vrijednost ova osobina imala je u 2014. godini 20,59 takođe. Kod sorte Rodika za kategoriju sjemena osnovno sjeme.

Ispitivana osobina broj zrna u klasu najveću zabilježenu vrijednost imala je u 2015. godini 76,92 kod ispitivane sorte Rodika za kategoriju sjemena predosnovno sjeme. Najmanju zabilježenu vrijednost ova osobina imala je u 2014. godini 64,39 kod sorte Rodika za kategoriju sjemena osnovno sjeme.

Osobina apsolutna masa 1000 zrna najveću zabilježenu vrijednost imala je u 2015. godini 46,91 kod ispitivane sorte Rodika za kategoriju sjemena osnovno sjeme. Najmanju zabilježenu vrijednost ova osobina imala je u 2014. godini 38,03 kod sorte Roksanda za kategoriju sjemena certificirano sjeme I. generacije.

Ispitivana osobina masa zrna u klasu najveću zabilježenu vrijednost imala je u 2015. godini 3,59 kod sorte Rodika za kategoriju sjemena predosnovno sjeme. Najmanju zabilježenu vrijednost ova osobina imala je u 2014. godini 2,57 kod sorte Roksanda za dvije kategorije sjemena predosnovno sjeme i certificirano sjeme I. generacije.

U tablici 4. prikazane su prosječne vrijednosti za pet ispitivanih osobina sorata pšenice prosječno po godinama ispitivanja za sve tri ispitivane sorte. 
N. Đurić i sur.: Fenotipske promjene pri sortnoj reprodukciji pšenice

Tablica 4. Srednje vrijednosti ispitivanih osobina pšenice u odnosu na ispitivanu sortu i godinu

Table 4 Mean values for investigated characteristics of wheat by investigated variety and year

\begin{tabular}{|c|c|c|c|c|c|c|}
\hline $\begin{array}{c}\text { Sorta } \\
\text { Variety }\end{array}$ & $\begin{array}{c}\text { Godina } \\
\text { Year }\end{array}$ & $\begin{array}{c}\text { Broj } \\
\text { sekundarnih } \\
\text { izdanaka } \\
\text { No. of } \\
\text { secondary } \\
\text { shoots }\end{array}$ & $\begin{array}{c}\text { Broj } \\
\text { klasića u } \\
\text { klasu } \\
\text { No. of } \\
\text { spikelets } \\
\text { in a spike }\end{array}$ & $\begin{array}{c}\text { Broj zrna } \\
\text { u klasu } \\
\text { No. of } \\
\text { grains in a } \\
\text { spike }\end{array}$ & $\begin{array}{c}\text { Apsolutna } \\
\text { masa 1000 } \\
\text { zrna (g) } \\
\text { Absolute } \\
1000 \text { grain } \\
\text { weight (g) }\end{array}$ & $\begin{array}{c}\text { Masa zrna } \\
\text { u klasu (g) } \\
\text { Grain } \\
\text { weight in a } \\
\text { spike (g) }\end{array}$ \\
\hline \multirow{4}{*}{ Kristina } & 2014 & 3,14 & 21,38 & 67,43 & 39,64 & 2,67 \\
\cline { 2 - 7 } & 2015 & 3,37 & 21,94 & 71,01 & 41,10 & 2,92 \\
\cline { 2 - 7 } & $\bar{X}$ & 3,26 & 21,66 & 69,22 & 40,37 & 2,80 \\
\hline \multirow{5}{*}{ Roksanda } & 2014 & 2,99 & 21,06 & 67,92 & 38,15 & 2,59 \\
\cline { 2 - 7 } & 2015 & 3,23 & 21,45 & 69,76 & 39,11 & 2,73 \\
\cline { 2 - 7 } Rodika & $\bar{X}$ & 3,11 & 21,25 & 68,84 & 38,64 & 2,66 \\
\hline & 2014 & 2,97 & 20,89 & 66,27 & 44,23 & 2,93 \\
\cline { 2 - 7 } & 2015 & 3,26 & 22,07 & 73,69 & 46,21 & 3,41 \\
\hline \multirow{2}{*}{} & $\bar{X}$ & 3,12 & 21,48 & 69,98 & 45,22 & 3,17 \\
\hline
\end{tabular}

Najveća prosječna vrijednost za obje godine ispitivanja za osobinu broj sekundarnih izdanaka iznosila je 3,26 za sortu Kristina. Najmanja prosječna vrijednost za ovu osobinu iznosila je 3,11 za sortu Roksanda. Ispitivana osobina broj sekundarnih izdanaka najveću zabilježenu vrijednost imala je u 2015. godini 3,37 kod sorte Kristina. Najmanju zabilježenu vrijednost ova osobina imala je u 2014. godini 2,97 kod sorte Rodika.

Ispitivana osobina broj klasića u klasu imala je najveću prosječnu vrijednost za obje ispitivane godine 21,66 kod sorte Kristina. Sorta Roksanda sa prosječnom vrijednošću 21,25 imala je najmanju zabilježenu vrijednost za promatranu osobinu. Ispitivana osobina broj klasića u klasu najveću zabilježenu vrijednost imala je u 2015. godini 22,07 kod sorte Rodika. Najmanju zabilježenu vrijednost ova osobina imala je u 2014. godini 20,89 također, kod sorte Rodika.

Sorta Rodika za ispitivanu osobinu broj zrna u klasu za obje ispitivane godine imala je najveću prosječnu vrijednost 69,98 , dok je sorta Kristina imala nešto nižu vrijednost za promatranu osobinu 69,22. Najmanju prosječnu vrijednost za obje godine 68,84 imala je sorta Roksanda. Ispitivana osobina broj 
N. Đurić i sur.: Fenotipske promjene pri sortnoj reprodukciji pšenice

zrna u klasu najveću zabilježenu vrijednost imala je u 2015. godini 73,69 kod sorte Rodika. Najmanju zabilježenu vrijednost ova osobina imala je u 2014. godini 66,27 također, kod sorte Rodika.

Ispitivana osobina apsolutna masa 1000 zrna imala je najveću prosječnu vrijednost, promatrano za obje godine 45,22 g kod sorte Rodika, dok je najmanju prosječnu vrijednost ova osobina imala kod sorte Roksanda 38,64. Ispitivana osobina apsolutna masa 1000 zrna najveću zabilježenu vrijednost imala je u 2015. godini 46,21 g kod sorte Rodika. Najmanju zabilježenu vrijednost ova osobina imala je u 2014. godini 38,15 kod sorte Roksanda.

Ispitivana osobina masa zrna u klasu imala je najveću prosječnu vrijednost za obje ispitivane godine $3,17 \mathrm{~g}$ kod sorte Rodika, dok je najmanja prosječna vrijednost za ovu osobinu iznosila 2,66 g kod sorte Roksanda. Ispitivana osobina masa zrna u klasu najveću zabilježenu vrijednost imala je u 2015. godini 3,41 kod sorte Rodika. Najmanju zabilježenu vrijednost ova osobina imala je u 2014. godini 2,59 kod sorte Roksanda.

Promatrajući prosječne vrijednosti po ispitivanim sortama možemo uočiti da je sorta Kristina prosječno za obje godine imala najveće prosječne vrijednosti za ispitivane osobine broj sekundarnih izdanaka i broj klasića u klasu, dok je sorta Rodika imala najveće prosječne vrijednosti za ostale ispitivane osobine broj zrna u klasu, apsolutna masa 1000 zrna i masa zrna u klasu.

Sorta Kristina ima veću sposobnost bokorenja od ostalih sorata u istim uvjetima 3,26, što je dobra predispozicija da formira veći broj fertilnih klasova, a samim tim i veći broj zrna kao i veći prinos zrna. Međutim, ova predispozicija nije i garancija, jer se kod drugih sorti može razviti manji broj krupnijih klasova. Na osnovi rezultata uočava se da za osobinu broj klasića u klasu to nije slučaj odnosno da Kristina ima klasove $\mathrm{s}$ većim brojem klasića u klasu. Međutim, kada se pogledaju druge osobine uočava se da Kristina nema bolje klasove po broju zrna i po masi zrna. Može se zaključiti da su druge sorte kompenzirale svoje slabije bokorenje s krupnijim klasovima, pa je zato bitno poznavati korelacije osobina.

U tablici 5. prikazane su prosječne vrijednosti za obje godine pet osobina pšenice po sortama i kategorijama sjemena. 
N. Đurić i sur.: Fenotipske promjene pri sortnoj reprodukciji pšenice

Tablica 5. Srednje vrijednosti ispitivanih osobina pšenice u odnosu na ispitivanu sortu i kategoriju sjemena

Table 5 Mean values for investigated characteristics of wheat by investigated variety and seed category

\begin{tabular}{|c|c|c|c|c|c|c|}
\hline $\begin{array}{l}\text { Sorta } \\
\text { Variety }\end{array}$ & $\begin{array}{c}\text { Kategorija } \\
\text { Category }\end{array}$ & $\begin{array}{c}\text { Broj } \\
\text { sekundarnih } \\
\text { izdanaka } \\
\text { No. of } \\
\text { secondary } \\
\text { shoots }\end{array}$ & $\begin{array}{c}\text { Broj } \\
\text { klasića u } \\
\text { klasu } \\
\text { No. of } \\
\text { spikelets } \\
\text { in a spike }\end{array}$ & $\begin{array}{l}\text { Broj zrna } \\
\text { u klasu } \\
\text { No. of } \\
\text { grains in a } \\
\text { spike }\end{array}$ & $\begin{array}{c}\text { Apsolutna } \\
\text { masa } 1000 \\
\text { zrna }(\mathrm{g}) \\
\text { Absolute } 1000 \\
\text { grain weight } \\
\text { (g) }\end{array}$ & $\begin{array}{c}\text { Masa zrna } \\
\mathrm{u} \text { klasu (g) } \\
\text { Grain } \\
\text { weight in } \\
\text { a spike (g) }\end{array}$ \\
\hline \multirow{3}{*}{ Kristina } & $\begin{array}{l}\text { Predosnovno } \\
\text { sjeme } \\
\text { Prebasic seed }\end{array}$ & 3,30 & 22,44 & 72,28 & 40,07 & 2,90 \\
\hline & $\begin{array}{l}\text { Osnovno } \\
\text { sjeme } \\
\text { Basic seed }\end{array}$ & 3,28 & 21,22 & 67,12 & 40,68 & 2,73 \\
\hline & $\begin{array}{c}\text { Certificirano } \\
\text { sjeme I gen. } \\
{\text { Certified } 1^{\text {st }}} \\
\text { generation } \\
\text { seed } \\
\end{array}$ & 3,20 & 21,32 & 68,27 & 40,37 & 2,76 \\
\hline \multirow{3}{*}{ Roksanda } & $\begin{array}{l}\text { Predosnovno } \\
\text { sjeme } \\
\text { Prebasic seed }\end{array}$ & 3,10 & 21,18 & 67,37 & 38,70 & 2,61 \\
\hline & $\begin{array}{l}\text { Osnovno } \\
\text { sjeme } \\
\text { Basic seed }\end{array}$ & 3,18 & 21,49 & 70,58 & 38,76 & 2,74 \\
\hline & $\begin{array}{l}\text { Certificirano } \\
\text { sjeme I gen. } \\
\text { Certified } 1^{\text {st }} \\
\text { generation } \\
\text { seed }\end{array}$ & 3,06 & 21,10 & 68,57 & 38,45 & 2,64 \\
\hline \multirow{3}{*}{ Rodika } & $\begin{array}{l}\text { Predosnovno } \\
\text { sjeme } \\
\text { Prebasic seed }\end{array}$ & 3,19 & 22,15 & 72,75 & 46,22 & 3,36 \\
\hline & $\begin{array}{l}\text { Osnovno } \\
\text { sjeme } \\
\text { Basic seed }\end{array}$ & 3,09 & 21,19 & 68,72 & 45,48 & 3,13 \\
\hline & $\begin{array}{l}\text { Certificirano } \\
\text { sjeme I gen. } \\
\text { Certified } 1^{\text {st }} \\
\text { generation } \\
\text { seed }\end{array}$ & 3,07 & 21,10 & 68,47 & 44,09 & 3,02 \\
\hline
\end{tabular}


N. Đurić i sur.: Fenotipske promjene pri sortnoj reprodukciji pšenice

Za prvu ispitivanu osobinu broj sekundarnih izdanaka najveću prosječnu vrijednost za obje ispitivane godine imala je sorta Kristina za kategoriju sjemena predosnovno sjeme i iznosila je 3,30 kod iste sorte kategorija sjemena osnovno sjeme imala je takođe visoku prosječnu vrijednost 3,28 za poromatranu osobinu. Najmanju prosječnu vrijednost 3,06 za osobinu broj sekundarnih izdanaka imala je sorta Roksanda za kategoriju sjemena certificirano sjeme I. generacije. Također nisku prosječnu vrijednost 3,07 imala je sorta Rodika za kategoriju sjemena certificirano sjeme I. generacije.

Ispitivana osobina broj klasića u klasu imala je najveću prosječnu vrijednost za obje ispitivane godine 22,44 kod sorte Kristina u kategoriji sjemena predosnovno sjeme. Kategorija sjemena predosnovno sjeme kod Rodike imala je također, visoku vrijednost za ovu osobinu 22,15. Najmanju prosječnu vrijednost za obje godine promatrana osobina imala je kod Roksande i Rodike 21,10 za kategoriju certificirano sjeme I. generacije.

Za osobinu broj zrna u klasu najveća prosječna vrijednost za obje godine ispitivanja zabilježena je kod sorte Rodika 72,75 u kategoriji sjemena predosnovno sjeme. Sorta Kristina je takođe imala visoku prosječnu vrijednost za obje godine 72,28 za kategoriju sjemena predosnovno sjeme. Najmanja prosječna vrijednost za ispitivanu osobinu broj zrna u klasu 67,12 zabilježena je kod sorte Kristina u kategoriji sjemena osnovno sjeme. Manje prosječne vrijednosti za promatranu osobinu zabilježene su i kod Roksande za kategoriju sjemena predosnovno sjeme 67,37 .

Osobina apsolutna masa 1000 zrna imala je najveću prosječnu vrijednost za obje godine ispitivanja kod Rodike za kategoriju sjemena predosnovno sjeme 46,22 g, dok je najniža vrijednost ispitivane osobine zabilježena za kategoriju sjemena certificirano sjeme I generacije kod Roksande 38,45 g.

Ispitivana osobina masa zrna u klasu pokazala je najveću prosječnu vrijednost za obje ispitivane godine, 3,36 g za sortu Rodika u kategoriji sjemena predosnovno sjeme. Visoku prosječnu vrijednost za ovu osobinu Rodika je imala i za ostale dvije ispitivane kategorije sjemena. Osobina masa zrna u klasu imala je najmanju prosječnu vrijednost za obje ispitivane godine kod sorte Roksanda 2,61 g za kategoriju sjemena predosnovno sjeme kao i kod iste sorte 2,64 g za kategoriju sjemena certificirano sjeme I generacije.

U tablici 6. prikazane su prosječne vrijednosti za pet ispitivanih osobina sorata pšenice prosječno po godinama ispitivanja za tri kategorije sjemena. 
N. Đurić i sur.: Fenotipske promjene pri sortnoj reprodukciji pšenice

Tablica 6. Srednje vrijednosti ispitivanih osobina pšenice u odnosu na kategorije sjemena i godine

Table 6 Mean values for investigated characteristics of wheat by seed categproes and years

\begin{tabular}{|c|c|c|c|c|c|c|}
\hline $\begin{array}{l}\text { Kategorija } \\
\text { Category }\end{array}$ & $\begin{array}{l}\text { Godina } \\
\text { Year }\end{array}$ & $\begin{array}{c}\text { Broj } \\
\text { sekundarnih } \\
\text { izdanaka } \\
\text { No. of } \\
\text { secondary } \\
\text { shoots }\end{array}$ & $\begin{array}{c}\text { Broj } \\
\text { klasića u } \\
\text { klasu } \\
\text { No. of } \\
\text { spikelets } \\
\text { in a spike }\end{array}$ & $\begin{array}{c}\text { Broj zrna } \\
\text { u klasu } \\
\text { No. of } \\
\text { grains in a } \\
\text { spike }\end{array}$ & $\begin{array}{c}\text { Apsolutna } \\
\text { masa } 1000 \\
\text { zrna (g) } \\
\text { Absolute } 1000 \\
\text { grain weight } \\
\text { (g) }\end{array}$ & $\begin{array}{l}\text { Masa zrna u } \\
\text { klasu }(\mathrm{g}) \\
\text { Grain } \\
\text { weight in a } \\
\text { spike (g) }\end{array}$ \\
\hline \multirow{3}{*}{$\begin{array}{l}\text { Predosnovno } \\
\text { sjeme } \\
\text { Prebasic seed }\end{array}$} & 2014 & 3,10 & 21,57 & 68,59 & 41,09 & 2,82 \\
\hline & 2015 & 3,29 & 22,28 & 73,01 & 42,22 & 3,09 \\
\hline & $\bar{X}$ & 3,20 & 21,92 & 70,81 & 41,66 & 2,96 \\
\hline \multirow{3}{*}{$\begin{array}{l}\text { Osnovno sjeme } \\
\text { Basic seed }\end{array}$} & 2014 & 3,01 & 20,84 & 66,35 & 40,71 & 2,70 \\
\hline & 2015 & 3,35 & 21,76 & 71,26 & 42,50 & 3,03 \\
\hline & $\bar{X}$ & 3,18 & 21,30 & 68,81 & 41,61 & 2,87 \\
\hline \multirow{3}{*}{$\begin{array}{l}\text { Certificirano } \\
\text { sjeme I gen. } \\
\text { Certified } 1^{\text {st }} \\
\text { generation seed }\end{array}$} & 2014 & 3,00 & 20,92 & 66,68 & 40,22 & 2,68 \\
\hline & 2015 & 3,22 & 21,42 & 70,19 & 41,71 & 2,93 \\
\hline & $\bar{X}$ & 3,11 & 21,17 & 68,43 & 40,97 & 2,81 \\
\hline
\end{tabular}

Ispitivana osobina broj sekundarnih izdanaka imala je najveću vrijednost 3,20 za kategoriju sjemena predosnovno sjeme, također, kategorija sjemena osnovno sjeme imala je veću prosječnu vrijednost promatrane osobine 3,18. Najnižu vrijednost 3,11 imala je kategorija sjemena certificirano sjeme I. generacije. Ispitivana osobina broj sekundarnih izdanaka najveću zabilježenu vrijednost imala je u 2015. godini 3,35 kod kategorije sjemena osnovno sjeme. Najmanju zabilježenu vrijednost ova osobina imala je u 2014. godini 3,00 kod kategorije sjemena certificirano sjeme I. generacije

Najveću prosječnu vrijednost za osobinu broj klasića u klasu imala je kategorija sjemena predosnovno sjeme 21,92 dok je najmanja prosječna vrijednost 21,17 za ovu osobinu zabilježena u kategoriji sjemena certificirano sjeme I. generacije. Ispitivana osobina broj klasića u klasu najveću zabilježenu vrijednost imala je u 2015. godini 22,28 u kategoriji sjemena predosnovno sjeme. Najmanju zabilježenu vrijednost ova osobina imala je u 2014. godini 20,84 u kategoriji sjemena osnovno sjeme.

Ispitivana osobina broj zrna u klasu imala je najveću vrijednost 70,81 za kategoriju sjemena predosnovno sjeme, dok je najmanju vrijednost promatrana 
N. Đurić i sur.: Fenotipske promjene pri sortnoj reprodukciji pšenice

osobina imala za kategoriju sjemena certificirano sjeme I generacije 68,43. Ispitivana osobina broj zrna u klasu najveću zabilježenu vrijednost imala je u 2015. godini 73,01 kod kategorije sjemena predosnovno sjeme. Najmanju zabilježenu vrijednost ova osobina imala je u 2014. godini 66,35 u kategoriji sjemena osnovno sjeme.

Ispitivana osobina apsolutna masa 1000 zrna imala je najveću prosječnu vrijednost 41,66 g za kategoriju sjemena predosnovno sjeme, dok je najmanju vrijednost promatrana osobina imala za kategoriju sjemena certificirano sjeme I. generacije $40,97 \mathrm{~g}$. Ispitivana osobina apsolutna masa 1000 zrna najveću zabilježenu vrijednost imala je u 2015. godini, 42,50 u kategoriji sjemena osnovno sjeme. Najmanju zabilježenu vrijednost ova osobina imala je u 2014. godini 40,22 u kategoriji sjemena certificirano sjeme I. generacije.

Najveća prosječna vrijednost kod osobine masa zrna u klasu 2,96 g zabilježena je za kategoriju sjemena predosnovno sjeme. Najmanja prosječna vrijednost za datu osobinu zabilježena je za kategoriju sjemena certificirano sjeme I. generacije 2,81. Ispitivana osobina masa zrna u klasu najveću zabilježenu vrijednost imala je u 2015. godini 3,09 u kategoriji sjemena predosnovno sjeme. Najmanju zabilježenu vrijednost ova osobina imala je u 2014. godini u kategoriji sjemena certificirano sjeme I. generacije 2,68.

Kategorija sjemena predosnovno sjeme imala je najveće prosječne vrijednosti za obje godine ispitivanja i to za sve ispitivane osobine.

Predosnovno sjeme ima najveći broj klasića u klasu što pokazuju da se oni razvijaju na klasovima dužim nego kod ostalih kategorija sjemena i da imaju potencijal za formiranje većeg broja zrna nego ostale kategorije.

Iz tablice 6. se vidi da certificirano sjeme I. generacije ima najmanji broj i najsitnija zrna, što je logično, jer se ova kategorija sjemena proizvodi u najvećoj gustoći.

\section{ZAKLJUČAK}

Promatrajaći obje godine možemo zaključiti da su sve ispitivane osobine imale veće prosječne vrijednosti u drugoj godini ispitivanja. U drugoj godini izvođenja pokusa bilo je jače izraženo bokorenje, formiran je veći broj klasića, veći broj zrna, veća apsolutna masa 1000 zrna i veća masa zrna u klasu. Sagledavajući generalno prvu i drugu godinu izvođenja pokusa možemo zaključiti da je druga godina bila pogodnija za proizvodnju pšenice, jer je palo 
za $250 \mathrm{~mm}$ više padalina tijekom vegetacijskog perioda u odnosu na prvu godinu izvođenja pokusa, a prosječne tempeature su pritom bile niže.

Ovako dobiveni rezultat pokazuje da sjemenarstvo pšenice i izbor sorata zavise u velikoj mjeri o agroekološkim uvjetima, na koje i treba obratiti pažnju pri izboru sortimenta pšenice. Na te promjene oplemenjivači i selekcionari ne mogu utjecati, jer se nalaze pod utjecajem ekoloških faktora kao što su: padavine, temperatura i dr.

$\mathrm{Na}$ osnovu prosječnih vrijednosti ispitivanih sorata pšenice $u$ obje ispitivane godine sorta Kristina je imala najveće vrijednosti sljedećih ispitivanih osobina: broj sekundarnih izdanaka $(3,26)$ i broj klasića u klasu $(21,66)$. Dok je sorta Rodika imala najveće prosječne vrijednosti za ostale ispitivane osobine: broj zrna u klasu $(69,98)$, apsolutna masa 1000 zrna $(45,22)$ i masa zrna u klasu $(3,17 \mathrm{~g})$.

Od svih ispitivanih sorata $\mathrm{u}$ istim ekološkim uvjetima sorta Kristina ima veću sposobnost bokorenja, što predstavlja dobru genetičku predispoziciju da formira veći broj fertilnih klasova. Na osnovu ove predispozicije moguće je očekivati i veći broj zrna i veći prinos zrna. Međutim, kada se analiziraju druge osobine uočava se da sorte Roksanda i Rodika imaju bolje klasove po broju i masi zrna. Na osnovi iznijetog može se zaključiti da su sorte pšenice Roksanda i Rodika kompenzirale svoje slabije bokorenje s krupnijim klasovima.

Kategorija sjemena predosnovno sjeme imala je najveće prosječne vrijednosti za obje godine izvođenja pokusa za ispitivane osobine: broj sekundarnih izdanaka, broj klasića u klasu i broj zrna u klasu, što je i logično, jer se kategorija predosnovno sjeme sije u najrjeđem sklopu pa biljke imaju najveći vegetacijski prostor a samim tim i fenotipski su najrobusnije. Kategorija sjemena osnovno sjeme imala je veće vrijednosti za sljedeće osobine: apsolutna masa 1000 zrna i masa zrna u klasu.

Kategorija sjemena predosnovno sjeme ima najveći broj klasića u klasu, što pokazuje da se oni razvijaju na dužim klasovima nego ostale kategorije sjemena. Kategorija sjemena predosnovno sjeme na osnovi ove karakteristike ima potencijal za formiranje većeg broja zrna u klasu nego ostale ispitivane kategorije sjemena.

Kategorija sjemena certificirano sjeme I. generacije ima najmanji broj i najsitnija zrna što je i logično jer se ova kategorija sjemena proizvodi u najvećoj gustoći. 
N. Đurić i sur.: Fenotipske promjene pri sortnoj reprodukciji pšenice

\section{LITERATURA}

1. Anderson, W.K. \& Barclay, J. (1991.): Evidence for differences between three wheat cultivars in yield response to plant population. Australian Journal of Agricultural Research 42, 701-713.

2. Akram, Z., Ajmal, S.U., Munir, M. (2008.): Estimation of correlation coefficient among some yield parameters of wheat under rainfed conditions. Pak. J. Bot., 40(4), 1777, 1781.

3. Dimitrijević, M., Petrović, S., Belić, M., Vuković, N. (2006.): Fenotipska varijacija parametara klasa pšenice na meliorisanom solonjecu. Selekcija i sjemenarstvo. 12/1-2, 27-33.

4. Đurić, N., Garalejić, B., Krgović, S., Trkulja, V., Kačarević, A., Janković, S. (2010.): Uticaj gustine setve na prinos nekih sorata ozime pšenice. Zbornik naučnih radova Instituta PKB Agroekonomik,16/1-2, 15-19.

5. Đurić N. (2013): Fenotipske promene i održanje genetičkog identiteta pri sortnoj reprodukciji pšenice. Doktorska disertacija, Poljoprivredni fakultet, Beograd.

6. Đurić, N., B. Kresović, Đ. Glamočlija (2015.): Sistemi konvencionalne i organske proizvodnje ratarskih useva. Monografija, Institut PKB Agroekonomik. ISBN 978-86-89859-01-0, COBISS.SR-ID 218749452, CIP 633.1/.7,631.147

7. Glamočlija, Đ. (2012.): Posebno ratarstvo. Žita i zrnene mahunarke. Poljoprivredni fakultet, Beograd.

8. Munkvold, J.D., Laudencia-Chingcuanco, D., Sorrells, M.E. (2013.): Systems genetics of environmental response in the mature wheat embryo.Genetics.194(1):265-77.

9. Natural Sciences Repository (2010.): The effect of the conditions of seed reproduction of winter wheat on morphological and biological varietal changes. Collection of works of post graduates and young scientific research workers. http://triscience.com/Plant/Seed/the-effect-of-the-conditions-of-seedreproduction-of-winter-wheat-on-morphological-and-biological-varietalchanges-collection-of-works-of-post-graduates-and-young-scientific-researchworkers/doculite_view

10. Prodanović, S., Mandić, D., Rajčević, B., Ranđelović, V., Dimitrijević, B. (2009.): Komparativne vrijednosti osobina pšenice kod individualnih biljaka $\mathrm{i}$ biljaka u usevu. Zbornik naučnih radova Instituta PKB Agroekonomik, 15/1-2, 27-31.

11. Petrović, S., Dimitrijević, M., Kraljević-Balalić, M. (2000.): Genotipska i fenotipska međuzavisnost komponenata prinosa pšenice (Triticum aestivum L.). Letopis naučnih radova Poljoprivrednog fakulteta u Novom Sadu 24/1-2, 133144. 
Adrese autora - Author addresses:

Primljeno-received:

Dr Nenad Đurić, docent

tel: +38124712 209

e-mail: nenad.djuric@outlook.com,

Dr Gorica Cvijanović, redovni profesor

tel: +38124712 209

e-mail: cvijagor@yahoo.com,

Dr Gordana Dozet, izvanredni profesor

tel: +38124712 209

e-mail: gdozet@biofarming.edu.rs

Sufyan Abuatwarat, doktorant

tel: +38124712 209

e-mail: sanfoor8300@yahoo.com

Univerzitet „Džon Nezbit“", Beograd

Fakultet za biofarming, Bačka Topola

Maršala Tita, broj 39

24300 Bačka Topola, Srbija

Dr Gordana Branković, docent

tel: +381114413239

e-mail: gbrankovic@agrif.bg.ac.rs,

Vojin Cvijanović, doktorant

tel: +381 114413239

e-mail: cvija91@yahoo.com

Univerzitet u Beogradu, Beograd

Poljoprivredni fakultet, Beograd

Nemanjina, broj 6

11080 Beograd-Zemun, Srbija 